\title{
Miks kasutada narratiivi? Lugu narratiivist
}

\author{
Lynn McAlpine ${ }^{\mathrm{ab} 1}$ \\ a Oxfordi Ülikool \\ ${ }^{b}$ McGilli Ülikool
}

\begin{abstract}
Annotatsioon
Narratiiv on üks paljudest kvalitatiivsetest uurimismeetoditest, mille abil saab koguda ja analüüsida andmeid ning esitada uurimistulemusi, kuid sellest hoolimata ei kasutata seda nii sageli kui näiteks juhtumiuuringuid. Artikkel annab võimaluse heita pilk narratiivi kasutamisele selle teadlase vaatenurgast, kes on viimase kümnendi jooksul uurinud selle meetodi abil järjepidevalt noorte teadlaste doktorantide ning kraadi omandanud ja karjääri alustavate inimeste - kogemusi. See on aidanud mõista nii narratiivi pakutavaid võimalusi kui ka sellega kaasnevaid piiranguid. Artiklis tutvustatakse esmalt narratiiviuuringuid laiemalt ning seejärel selgitatakse autori kümneaastase narratiiviuuringuga seotud mõttekäike, protsesse ja toiminguid, sealhulgas narratiiviga kaasnevat loomingulist potentsiaali. Eesmärk on tekitada teistes teadlastes soov kaaluda narratiivi kasutamise võimalusi, kui see sobitub nende epistemoloogilise käsitlusviisiga.
\end{abstract}

Võtmesõnad: kvalitatiivsed uurimismeetodid, narratiiviuuring, loomingulisus

\section{Kontekst}

Nelikümmend aastat tagasi kirjutasin oma doktoritööd ja tundsin, et olen võõrandumas objektivistlikust käsitlusviisist, mis oli sel ajal levinud nii hariduses kui ka sotsiaalteadustes üldisemalt. Pedagoogi ja nooremteadurina oli mul keeruline mõtestada teadustöö tegemist viisil, mis, nagu mulle tundus, oli lahutatud kogemustest, arvestades eelkõige asjaolu, et see võimaldas tungida uuringus osalejate ellu, kuid tõi samas minimaalset kasu. Õnneks tegutsesin ülikoolis, kus narratiiv kui uurimismeetod oli uue teadusliku käsitlusviisina just kasutusele võetud ning kus keskenduti eeskätt sellele, kuidas haridustöötajad saaksid oma ópetamismeetodeid selle abil paremini teadvustada ja mõtestada ning seeläbi ka sihiteadlikumalt rakendada. Otsekohe tundus mulle, et selline käsitlusviis on mõjukas, ning ma

1 University of Oxford, Department of Education, 15 Norham Gardens Oxford OX2 6PY, United Kingdom; lynn.mcalpine@learning.ox.ac.uk 
suutsin oma väitekirja lõpetada nii, et see oli minu jaoks mõtestatud ja pakkus ehk teatavat kasu ka uuringus osalejatele. See ammune kogemus tekitas minus elukestva huvi kasutada oma uurimismeetodi elemendina narratiivi (ja kogemuste üle järelemõtlemist), mis ilmneb väga selgelt mu viimases, kümnendipikkuses kvalitatiivsete narrativiuuringute programmis, mille raames uuritakse karjääri alustavate teadlaste elu. Loodetavasti suudan äratada lugejas piisavat huvi, et tal tekiks tahtmine narratiiviga lähemalt tutvuda.

Kursiivis tekst eespool eristub annotatsioonist, kuigi ma väidan, et see teenib suuresti sama eesmärki - tekitada lugejas soovi tekstiga tutvuda. See on hõlpsalt äratuntav lugu, mis sisaldab mõningaid narratiivi kui uurimisvahendi põhiaspekte. Sellega luuakse n-ö minakuvand - mina, jutustaja või peategelane, kes loos aktiivselt osaleb. Minu loos on narratiivi jooni: see näitab mu eesmärke ja kavatsusi, seda, kuidas ma tegevusega edenesin, luues sündmuste vahel seoseid, ning osutab aja mõjule ja tutvustab kogemuse isiklikku tähendust (Coulter \& Smith, 2009). Nagu igast loost, on ka sellest paljugi välja jäetud, sest tegemist on looga, mida räägitakse konkreetses kontekstis (artiklis) konkreetsetele lugejatele (eeldan, et olete huvitatud ja teadlikud kvalitatiivsetest meetoditest, kuid narratiiviga seoses minust vähem kogenud).

\section{Narratiiv kui igapäevasündmus}

Kas me oleme sellele mõelnud või mitte, on nii suuliste kui ka kirjalike narratiivide puhul tegemist selgesti eristatava väljenduslaadiga, mida me kõik teame ja kasutame. Tegelikult räägime kõik iga päev oma elust lugusid, sest narratiiv annab inimesele praktilised vahendid, mille abil luua oma elu kohta sidus süžee, millel on algus, keskpaik ja lõpp - minevik, olevik ja tulevik. Sõltumata sellest, kas seda räägitakse vaid iseendale või ka teistele, pakub iga jutustus lihtsat viisi muuta minevikus saadud kogemused mõtestatud õppimisvõimaluseks, teha kindlaks enda ja teiste koht jutustuses ning lasta aimata tulevikku.

Narratiivides on ühendatud ajalikkuse element, sotsiaalne kontekst, komplitseerivad sündmused ja hinnangut sisaldav järeldus, mis moodustavad üheskoos sidusa loo. Kõige olulisem on asjaolu, et jutustaja või peategelane on jutustuses aktiivne osaline, mitte kõrvalseisja (Elliott, 2005). Seega võimaldab narratiiv heita pilgu identiteedi ülesehitamise protsessile (Riessman, 2008). Narratiivide loomist ja esitamist kasutavad inimesed eesmärgiga kujundada ja ümber kujundada seda, kes nad on olnud, kes nad on praegu ja kelleks nad loodavad saada. Kuna narratiivid pakuvad pikaajalisi etalone, mida jäljendada, millele vastata või mida ületada (Sfard \& Prusak, 2005), võivad need lood mõjutada ka jutustaja ettekujutust iseendast ja 
seda, kuidas ta otsustab tegutseda (Holley \& Colyar, 2009). Lisaks võivad narratiivid juhul, kui neid räägitakse teistele, mõjutada teiste inimeste ettekujutust loo jutustajast.

Loodetavasti aitab narratiivi asetamine igapäevase tegevuse raamistikku mõelda sellest kui uurimismeetodist, mida me kõik teataval määral tunneme. Allpool tutvustan neile, kes ei ole narratiiviga ehk nii tuttavad, seda, milles seisneb minu arvates selle meetodi potentsiaal, kuid näitan ka mõningaid ohukohti, millele tuleb - nagu kõikide teaduslike käsitlusviiside puhul - tähelepanu pöörata. Esmalt tutvustan konteksti, et selgitada, miks sotsiaalteadlased peavad seda kasulikuks meetodiks, ning seejärel vaatlen mitmesuguseid võimalikke metoodilisi käsitlusi ja eri võimalusi narratiivi kaasamiseks uurimisprotsessi. Sellele tuginedes kirjeldan täpsemalt, kuidas me oleme narratiivset käsitlusviisi viimase kümne aasta jooksul kasutanud, ning lõpuks arutan eetikaküsimusi ja narratiivi eeliseid, aga ka selle kasutamise piiratust.

\section{Narratiivi kasutamine uurimismeetodina}

Narratiiv on üks paljudest tõlgendavatest käsitlusviisidest, mida sotsiaalteadustes kasutatakse, kuigi ehk vähem tuntud kui juhtumiuuringud, etnograafia või põhistatud teooria ${ }^{2}$. Seda on kasutatud sotsioloogias, organisatsiooniuuringutes, soouuringutes ja hariduses ning see on tihedalt seotud biograafiaga, sest samamoodi nagu need hõlmab narratiiv lugude jutustamist ning kirjeldust (jutustust) sellest, kuidas üksikisikud kui enda tegevust juhtivad inimesed mõtestavad oma elusündmusi ja tegevusi.

Narratiivi kasutavad uurijad lähtuvad sageli eeldusest, et lugu on üks - kui mitte peamine - terviklik üksus, mis annab ülevaate inimeste kogemustest. Hariduses on selle kasutamine ehk enim tuntud õpetajate kogemusi kajastavate uuringute kaudu (mida ka mina oma doktoritöös käsitlesin), mille eesmärk on luua isiklikke praktilisi teadmisi - „õpetaja varasemate kogemuste kajastumine õpetaja praeguses füüsilises ja vaimses olekus ning tema tulevastes plaanides ja tegudes" (Connelly, Clandinin, \& He, 1997, lk 666). Seda küsitlemisvormi käsitati võimalusena koguda ja väärtustada teadmisi, mida ei ole õpetajate hariduses alati väärtustatud nimelt neid, mis lähtuvad pigem kogemusest kui teadusuuringutest. Minu tegevusvaldkonnas, st kõrghariduses, võeti narratiiv kasutusele küll hiljem

2 Kuigi narratiivimetoodit kasutatakse põhiliselt kvalitatiivselt, saab seda kasutada ka kvantitatiivsetel ja kombineeritud meetoditel põhinevates uuringutes. Seda liiki uuringute selgitusi ja näiteid vt Elliott (2005). 
kui hariduses, kuid praegu uuritakse selle abil näiteks akadeemilise töö ja doktorantide tööga seotud arusaamu. Valdkonnast olenemata hõlmavad narratiiviuuringud mitmesuguseid metodoloogilisi käsitlusviise ning andmete koostamise, kogumise, analüüsimise ja esitamise võimalusi. Tutvustan mõlemat vaatenurka, tuues näiteid kõrgharidusvaldkonnas avaldatud uurimistulemuste kohta.

\section{Mitmesugused metoodikad}

Kasutusel on kolm peamist metodoloogilist käsitlusviisi (Elliott, 2005; Pinnegar \& Daynes, 2007). Meie uuringu aluseks olevat metoodikat esindab kõige paremini neist teine, naturalistlik käsitlusviis.

- Sotsiaalkultuuriline käsitlusviis. Keskendutakse laiaulatuslikele kultuuripõhistele narratiividele, mis mõjutavad üksikisikute kogemusi. Selle käsitlusviisi puhul esitatakse järgmised küsimused: mis lugusid inimesed räägivad ja kasutavad, et olla osake kohalikest tavadest, ning kuidas kujutavad sellised lood endast kultuuripärandit, st kuidas põhinevad need ühistel narratiividel, millest üksikisikud saavad lähtuda ja mida kohandada, et need kajastaksid paremini nende oma kogemusi?

- Naturalistlik käsitlusviis. Keskendutakse olulisi teemasid käsitlevate lugude sisu üksikasjalikule kirjeldamisele. Kogutud andmete põhjal esitatakse seega järgmised küsimused: millised on selle isiku kogemused, mida need kogemused tema jaoks tähendavad ning milliseid komplitseerivaid tegevusi ja hinnangulisi aspekte on rõhutatud?

- Kirjanduslik käsitlusviis. Seda kasutatakse harva eraldiseisvalt, kuid see hõlmatakse sageli ühte kahest ülejäänud käsitlusviisist. Keskendutakse arutluskäigule, mille kaudu kirjeldavad inimesed oma kogemusi: millised on narratiivides domineerivad kujundid ja metafoorid (konkreetne keelekasutus), mis kajastavad olulist mõju kogemustele; ning millised narratiivi positiivsed ja negatiivsed jooned (osalejad, tegevuspaigad, süžeeliinid) on jutustustes valdavad?

\section{Mitmesugused uurimisprotsessid}

Nagu paljusid teisi metodoloogilisi käsitlusviise, saab ka narratiivi vaatenurga kaasata kogu uurimisprotsessi ülesehitusse või kasutada seda ainult mõnes kohas.

- Andmete kogumine ja mõtestamine. Paljud narratiivi kasutavad uuringud tuginevad suulistele jutustustele, st hiljem transkribeeritud intervjuudele, kuid uuringutes võidakse andmeid koguda ka tekstipõhiselt, näiteks struktureerimata päevikutest või poolstruktureeritud 
tegevuspäevikutest. Peale selle võib selliseid andmeid mõtestada eraldiseisvate narratiividena, st sidusate lugudena sellest, kuidas osalejad jutustavad nendega juhtunust. See ei välista aga narratiivi kasutamist uurimisprotsessi hilisemates etappides. Näiteks kasutasid Churchman ja King (2009) pabertahvli lehtedele tehtud märkusi, et jälgida nn maailmakohviku (world café) meetodil korraldatud ürituse käigus toimunud arutelu (mis ilmselgelt ei ole narratiiv), et luua pildikesed töökohal saadud kogemustest (andmete analüüsimine), mida nad kasutasid tulemuste saamiseks.

- Andmete analüüsimine. Hoolimata narratiivi uurimise metodoloogilisest poolest, on narratiivianalüüsi esmane eesmärk mõista üksikisiku kogemustest lähtuva tähenduse kujunemise kronoloogiat, olenemata sellest, kas lõppeesmärk on säilitada idiosünkraatiline jutustus kogemustest (naturalistlik käsitlusviis) või püüda leida ühiseid kultuurilisi narratiive (sotsiaalkultuuriline käsitlusviis) või kogemusi määratlevaid jõulisi metafoore ja neid edasiandvat keelekasutust (kirjanduslik käsitlusviis). Seepärast on analüüsi eesmärk tagada, et „lugu jääks tervikuks, tuletades teooriaid juhtumist, mitte mitmete juhtumite osaks olevatest teemadest" (Riessman, 2008, lk 53). Selline vaatenurk on vastuolus paljude muude traditsiooniliste uurimismeetodite raames kasutatava temaatilise analüüsiga, mille puhul leide analüüsitakse ja korrastatakse esmalt teema, mitte üksikisiku kaupa (vt Miles \& Huberman, 1994). Osalejate narratiivide analüüsimiseks on loomulikult võimalik kasutada ka traditsioonilisemaid viise, näiteks temaatilist analüüsi.

- Andmete esitamine. Mitte kõikides narratiiviuuringutes ei kasutata analüüsitulemuste esitamiseks uurija koostatud narratiivseid jutustusi, kuid nendes, kus seda tehakse, võetakse osaleja kogemusi kajastavate madala järeldustasemega jutustuste koostamisel tavaliselt abiks kirjanduslikud elemendid, näiteks süžee, selle edenemist toetavad tegelaskujud ja isik, kelle vaatenurgast lugu jutustatakse (esimene või kolmas isik) (Holley \& Colyar, 2009). Isegi kui teadlased loovad oma uuringute esitamiseks narratiivseid lühipilte või -ülevaateid, kasutavad paljud neist andmete esitamiseks muid vahendeid, mis tuginevad traditsioonilisematele temaatilise analüüsi vormidele, näiteks teemade kokkuvõtted, millele on sageli lisatud väljavõtted intervjuudest. Narratiivseid elemente võidakse tulemuste esitamiseks loomulikult kasutada ka paljudes sellistes uuringutes, mis ise ei põhine narratiivil.

Oma uuringus kogume andmeid osalejate narratiividena, juhindume narratiivi analüüsimisel naturalistlikust käsitlusviisist, millele järgneb kõiki juhtumeid hõlmav temaatiline analüüs, ning kasutame andmete 
esitamisel nii lühipilte kui ka teemasid. Alljärgnevad kirjeldused pakuvad loodetavasti konkreetseid näiteid kõnealuse kolme käsitlusviisi kohta, samuti selle kohta, kuidas narratiivset vaatenurka uurimisprotsessis rakendati (alla joonitud).

- Sotsiaalkultuuriline käsitlusviis. Ylijoki (2001) uuris üliõpilase ja juhendaja suhteid ning probleeme, millega puututakse kokku magistritöö kirjutamise ajal. Tema lähtepunktiks oli väide, et kultuuris domineerivad lood asjaomase protsessi kohta annavad üksikisikutele vahendid omaenda kogemuste mõtestamiseks. Ta soovis kindlaks teha, millised need kultuurilised lood on. Ta tugines 72 intervjuule (individuaalsed ja sihtrühmadega tehtud intervjuud) nelja eriala magistrantidega, kelle õpingud olid erineval kaugusel. Ta ei mõtestanud neid intervjuusid kui narratiive, sest üliõpilaste jutustuste ajaline järjestus ja teemad muutusid, kuid ta kasutas narratiivset analüüsi, et anda üliópilaste väitekirja kirjutamise protsessi kirjeldusele sidusus ja ajaline järjepidevus. Seda tehes otsis ta andmetes sarnasusi, et koostada neli valdavat nn ideaaltüübi lugu. Need neli ideaaltüüpi jagunesid ühtlaselt kõikides väitekirja kirjutamise etappides olevate üliõpilaste vahel. Kõikide ideaaltüüpide puhul olid süžee ülesehitus, sisuliinid ja peategelase (s.o üliõpilase) roll erinevad (kirjanduslik analüüs). Ylijoki ei kasutanud uurija koostatud narratiive iga ideaaltüübi tutvustamiseks, vaid pigem kirjeldas nende olemust ja erinevusi. Ta väitis, et üliõpilased tuginevad nendele ideaaltüüpidele ja kohandavad neid, et mõtestada oma väitekirja kirjutamise protsessi.

- Naturalistlik käsitlusviis. Cumming (2009) viis läbi ühe loodusteaduste doktorandi narratiivse juhtumiuuringu tõendamaks, et normatiivsed eeldused - mida ta nimetas ortodoksseks mudeliks - loodusteaduste doktoriõppe kohta peidavad endas olulisi erinevusi. Ta soovis uurida doktoriõppes osalejate n-ö mikromaailma. Tema eesmärk oli dokumenteerida selle eripärad ja keerukus seoses ühe loodusteaduste doktorandi kogemustega, ühendades mitu kõnealuse üliõpilasega tehtud intervjuud (transkribeeritud narratiividena) tema juhendajate intervjuudega. Nende andmete põhjal koostas ta eraldiseisva narratiivse juhtumi (uurija koostatud narratiiv), mida ta nimetas mitmehäälseks, kuna üliõpilase kogemused olid selles sünteesitud tema juhendajate omadega, ilma et Cumming oleks seda eraldi kommenteerinud. Seejärel esitas ta oma narratiivse tõlgenduse: oma seisukohad selle kohta, kuidas üliõpilase narratiiv ortodokssest mudelist mitmeti erines. Eelkõige täheldas ta, kuidas narratiivist ilmnes üliõpilase tegevus oma elu juhtimisel, samas toetasid teda ka juhendajad. (Kõnealune uuring esindab paljusid 
naturalistlikke narratiivseid uuringuid, sest selles uuritakse ühte juhtumit, kuigi on tavatu, et sellesse on kaasatud ka teiste isikute vaatenurgad.)

- Kirjanduslik käsitlusviis. Hopwood ja Paulson (2012) seadsid lähtekohaks eelduse, et doktorantide kogemuste uurimisel on eiratud keha ja käsitletud eelisjärjekorras vaimu, ning väitsid, et ka kehasse tuleb tõsiselt suhtuda. Nad võtsid ülesandeks tõendada kehaliste kogemuste mitmekesisust ning seda, kui tähenduslik ja oluline on doktorantide puhul kehaline kogemus, vaadeldes doktorantide keelekasutust. Nad lähtusid 33 sotsiaalteaduste doktorandi narratiivist - nii suulistest (intervjuud) kui ka kirjalikest (iganädalased päevikud). Kasutades üht kindlat diskursuseanalüüsi vormi, tõid nad näiteid selle kohta, kuidas keel määratleb ja kirjeldab kehasid (nt sugu, rasedus, rass, noorus/iga, füüsiline vorm, ebatavalised kehad, nt düsleksia) ja emotsioone (nt nutmine, adrenaliin, kokkuvarisemine, tardumine, rõõmust tantsimine, haigus, oksendamine, ärevus, viha, pettumus). Nad esitasid tulemused temaatiliselt ja uurija koostatud narratiive välja ei pakkunud. Selle asemel kasutasid nad keha tajumise näitlikustamiseks väljavõtteid intervjuudest. Hopwood ja Paulson järeldasid, et doktorikraadi omandamine on möödapääsmatult ka kehaline kogemus.

\section{Kuidas käsitletakse narratiiviuuringute raames meie mõtteid ja tegusid?}

\section{Uuringu kontekst}

Seda uuringut ajendasid meid korraldama üsna pragmaatilised kaalutlused: uurida olulist ja pakilist probleemi - doktoriõpingute katkestamist. Kui uuringud olid kestnud umbes aasta, muutsime oma esialgset huvikeset, rõhutades õpingute katkestamise asemel vajadust õppida akadeemilise töö tegemist, mistõttu jälgisime osalejaid pärast kraadi omandamist. Nähes neid alustamas oma karjääri, tekkis meil huvi dokumenteerida kvalitatiivselt iga üksikisiku ainukordne teekond doktoriõppest eri karjäärivalikuteni, pöörates eritähelepanu kavatsuste ja vastupidavuse rolli mõistmisele doktorikraadile järgneva karjääri kujundamisel (McAlpine, 2014; McAlpine, Amundsen, \& Turner, 2014). Seega oleme enam kui kümne aasta jooksul kasutanud naturalistlikku narratiivset pikiuuringut, et jälgida rohkem kui sadat Kanadast või Ühendkuningriigist pärit teadlast ja sotsiaalteadlast vähemalt 18 kuu jooksul ning 48 teadlast 4-6aastaste ajavahemike vältel. Meie uuringut eristab enamikust muudest naturalistlikest narratiiviuuringutest asjaolu, et rakendame pikiuurimuslikku vaatenurka ja jälgime 
suurt hulka isikuid - enamikus teistes uuringutes uuritakse ühte või mõnda üksikut isikut kindlal ajahetkel. (Nii meie epistemoloogilise kui ka metodoloogilise käsitlusviisi põhjalikum selgitus on esitatud McAlpine'i, Amundseni ja Turneri 2013. aasta artiklis).

Meie epistemoloogilist käsitlusviisi asjaomases töös võib nimetada kriitiliselt realistlikuks (Archer, 2003). Seega tunneme huvi selle vastu, kuidas üksikisikud oma tegude kaudu oma elu juhivad, mis muu hulgas hõlmab jõupingutusi tajutavate tavade ja tegevuspõhimõtete vältimiseks, vaidlustamiseks või nende vastu võitlemiseks. Samamoodi nagu teised, ei tee me suurt vahet mõtlemisel, õppimisel ja identiteedi kujunemisel (Billett \& Somerville, 2004). Leidsime, et sellise epistemoloogiaga sobib hästi naturalistlik narratiivne metodoloogiline käsitlus, sest meid huvitas eeskätt iga teekonna eripärade dokumenteerimine ja mõistmine. Saime aru, et meie töö peab seisnema iga üksikisiku identiteedi kujunemistee jälgimises, lähtudes arusaamast, et identiteet hõlmab üksikisiku unikaalse identiteedi tajumise kestust, kombineerituna pigem isikliku muutumise tajumise kui stabiilsusega aja jooksul (Riessman, 2008). Uuringu alustamisest saadik oleme avaldanud ligikaudu 50 eelretsenseeritud artiklit. Neist enamik põhineb pikilõikelistel narratiiviuuringutel, mida tegelikult kasutatakse suhteliselt harva (nt McAlpine, ilmumas), kuid üksikutes artiklites on rakendatud ka levinumat käsitlusviisi - andmete ühekordset kogumist (nt McAlpine, 2016). Allpool esitan mõlemat liiki uuringute kokkuvõtte, nagu olen seda teinud eespool toodud kolme näite puhul.

\section{Kaks näidet}

Pikiuuringut kasutades uuris McAlpine (ilmumas) mitteakadeemilise karjär̈ri valinud kaheksa sotsiaalteadlase karjääriotsuste tegemise protsessi, jälgides neid alates kraadiõpingutest kuni kõrghariduse omandamisele järgnenud esimeste aastateni. Eesmärk oli mõista nende karjääriotsuste tegemise protsessi, sest üle poole doktorikraadi omandanutest lahkub akadeemilistest ringkondadest, kuid vähe andmeid on selle kohta, mis teid pidi nad oma valitud ametikohtadele jõuavad. 12-18kuulise tsükli jooksul koguti narratiivseid andmeid nelja ankeedi abil (neid on üksikasjalikumalt selgitatud allpool) ning tsüklit korrati vähemalt kolm korda. Need arvukad narratiivid võimaldasid mitmel viisil mõista iga üksikisiku karjääriplaane, otsuste tegemist ja kogemuste ajalist järjestust. Iga üksikisiku narratiive loeti korduvalt üle, et koostada juhtumi kokkuvõte, milles anti ülevaade sellest, kuidas nad kujutasid kraadiõppe jooksul ette doktoriõppele järgnevat karjääri ning kas ja kuidas nende karjääriplaanid aja 
jooksul muutusid. Nagu eespool märgitud, on selline analüütiline käsitlusviis narratiiviuuringute puhul tavapärane. Pärast kaheksa juhtumi kokkuvõtete koostamist võeti need aluseks kõiki juhtumeid hõlmavale analüüsile, mille eesmärk oli leida seaduspärasusi. Analüüs tõi välja erinevused seoses sellega, kui selge on ettekujutus karjäärist ning milline on karjäärialane strateegiline mõtlemine ja tegevus. Tulemustest, mis on esitatud nii lühipiltide kui ka teemadena koos intervjuude väljavõtetega, ilmneb, et kõige parem on hakata doktoriõppele järgnevat karjäärikõverat üles ehitama doktoriõppe alguses, kui tehakse otsus, milline peaks olema õppekava.

McAlpine (2016) uuris teekonda doktoriõppe lõpetamisest kuni esimese stipendiumi saamiseni uurimisrühma juhina, sest sõltumatuse saavutamine teadustöös avaldab akadeemilistele tulemustele olulist mõju. Narratiivil põhinevas uuringus dokumenteeriti, kuidas 16 teadlast kolmest ülikoolist töötasid soovitud positsiooni saavutamise nimel, ja käsitleti seejärel selle soovi täitumist. Intervjuu käigus jutustas osaleja tõusudest ja mõõnadest teekonnal doktoriõppest kuni esimese stipendiumini uurimisrühma juhina. Seda narratiivi täiendasid kahes vormis esitatud narratiivid: osaleja esitatud joonis sellest teekonnast ja CV (akadeemiline narratiiv). Visuaalse ja dialoogi vormis esitatud teabe kombineerimine pakkus eri võimalusi mõista osalejate eesmärke, tipphetki ja ebaõnnestumisi ning kogemuste ajalist järjestust. Sama analüüsimeetodit kasutas McAlpine (ilmumas), luues esmalt iga üksikisiku kogemustest juhtumi kokkuvõtte ning uurides seejärel kõiki juhtumeid seaduspärasuste leidmiseks. Tulemustest ilmnes emotsioonide keskne roll sageli pikaajalisel teekonnal uurimisrühma juhi positsiooni saavutamiseni; teekonnal, mis nõudis vastupidavust ja eneseusku, kui inimesed püüdsid oma eesmärke ellu viia, et saada karjääri edendamiseks vajalik rahastus.

\section{Kuidas me narratiivi kasutame?}

Narratiiviuuringute puhul on meie jaoks ehk kõige olulisem nende potentsiaal väärtustada erinevaid teadmiste omandamise viise (Pinnegar \& Daynes, 2007). Narratiivimetoodika kasutamine, eriti pikilõikeliselt ja võrdlemisi suurel arvul inimestel, võimaldab meil dokumenteerida mitmesuguseid ja muutuvaid viise mõista nii ühe isiku kui ka inimestevahelisi kogemusi. Lõpuks väidame, et kuna narratiiviuuringute aruanne võib sisaldada mitmeid vaatenurki kogemusele, võimaldab see anda läbielatud kogemustest mitmekesisema ja usutavama pildi. Järgnevalt käsitlen meie narratiivsete andmete kogumise, analüüsimise, koostamise ja esitamise üksikasju. 


\section{Narratiiv andmete kogumisel}

Nagu paljud teised interpreteerivad uurijad (Creswell, 2007), käsitame ka meie andmete kogumist läbirääkimistel põhineva vastastikuse suhtlemisena (Taylor, 2008), uurija ja osaleja koostöös toimuva tegevusena (Sfard \& Prusak, 2005), kusjuures mõlemad vastutavad ühiselt tekkiva loo eest. Need narratiivid kajastavad lugusid osalejate elust ning need on oma tekkehetkel konkreetset uurimiseesmärki silmas pidades meie palvel juba n-ö toimetatud, st piiratud koha, aja, vormi ja vestluskaaslasega.

Ühe narratiivide tuletamise võimalusena kasutasime poolstruktureeritud intervjuusid, lähtudes eeldusest, et intervjuudes tuleb tavaliselt välja vaid nende toimumise ajal oluline teave ning tähelepanuta võivad jääda kunagised tähtsad sündmused ja aja jooksul muutunud kogemused. Seega püüdsime koostada narratiivi nii igapäevastest kogemustest, mis mõjutavad üksikisiku tegelemist akadeemilise või doktoritööga, aga ka nende pikaajalist arengut mõjutavatest saavutustest ja probleemidest. Selle tulemusel kogusime elektroonilisi iganädalasi poolstruktureeritud tegevuspäevikuid. Aja möödudes otsustasime koguda narratiive veel kahes elektroonilises vormis: biograafilise küsimustiku ja enne intervjuud täidetava küsimustikuna ${ }^{3}$. Neid on kirjeldatud allpool samas järjekorras, milles neid 12-18kuulise (korduva) tsükli jooksul kasutati.

\section{Biograafiline küsimustik}

See täidetakse andmete kogumise tsükli esimese sammuna, et saada põhiteavet isiku mineviku, hetkeolukorra ja tulevikuplaanide kohta, st praegune roll/staatus, ajakohastatud andmed avaldatud teadusartiklite ja esitluste kohta, eriala muutumine jne.

\section{Iganädalane tegevuspäevik}

Päevikuid kogutakse regulaarselt (iga 4-6 nädala tagant) ja need on struktureeritud, et hankida osalejate igapäevaste kogemustega seotud narratiive asjaomasel nädalal. Need sisaldavad lühivastustega küsimusi (mis sageli hõlmavad küsimust „Miks?”, et saada ülevaade kogemuse tähendusest), lauseid, kus osalejad täidavad lüngad, ning loetelusid, millest tuleb valida sobiv variant. Osalejad esitavad teavet selle kohta, kui palju aega kulutasid nad nädala jooksul tööle, millise tegevusega nad tegelesid, kellega nad

3 Uus tehnoloogia on muutnud mitmesuguses vormis andmete kogumise, salvestamise ja analüüsimise üha lihtsamaks. 
lävisid, kes on nende jaoks olulised isikud ja miks nad on olulised, mis probleemid ette tulid ja kuidas need lahendati jne. (Hiljuti analüüsisime, kas päevikud jutustavad meile kogemustest teistsuguse loo kui intervjuud, ja leidsime, et nii see on, vt McAlpine \& Amundsen, 2015). Osalejad on märkinud, et päevikute täitmine oli neile endale kasulik, võimaldades tajuda oma edusamme aja jooksul (Alexander, Harris-Huemmert, \& McAlpine, 2014). (Lisas 1 on esitatud täidetud päeviku näidis (vastuseid on lühendamise eesmärgil toimetatud) ja tutvustatud, mis liiki narratiive selline struktuur pakub.)

\section{Enne intervjuud täidetav küsimustik}

Erinevalt päevikutest on enne intervjuud täidetavad küsimustikud kavandatud eesmärgiga pakkuda laiemat vaatenurka ja tagasivaadet eelmisele aastale. Küsimustik saadetakse osalejatele umbes kümne kuu möödumisel, vahetult enne nendega tehtavat intervjuud. Neil palutakse panna kirja oma märkused selle kohta, mida nad peavad olulisteks sündmusteks või saavutusteks, ja esitada meile ajakohast teavet kõikide muude eelneva aasta jooksul toimunud muutuste kohta. Eesmärk on saada ülevaade nende jaoks olulisest teabest, mida me ei pruukinud päevikutest teada saada.

\section{Intervjuu}

Intervjuuks valmistudes loeb uurija üle kõik osaleja esitatud narratiivid, et sõnastada intervjuu eri osade jaoks küsimused. Püüame teha nii, et igal aastal oleks üks ja sama intervjueerija, kuigi alati ei ole see võimalik. Intervjuu alguses esitatakse hulk küsimusi, mis on seotud eelmise aasta intervjuuga ja enne intervjuud täidetavas küsimustikus tõstatunud huvitavate teemadega. Teises osas palutakse inimestel lähemalt täpsustada mõningaid kogemusi, mida nad kirjeldasid oma päevikus ja mida me peame asjakohaseks. Kolmas osa on aastati erinev (vt järgmine lõik). Viimases osas küsitakse osalejatelt nende tulevikuplaane ja -lootusi (nii ühe kui ka viie aasta plaanis).

\section{Visuaalsete meetoditega täiendatud intervjuud}

Oleme oma intervjuudesse kaasanud ka visuaalsed meetodid, sest need aitavad saada kogemustest vahetuma ja spontaansema pildi (Bagnoli, 2009). Suuline või kirjalik tõlgendus osaleja tööst on analüüsi toetamisel siiski määrava tähtsusega (Buckingham, 2009). Seda ilmestavad järgmised näited. 
- McAlpine'i uuringus (2016) joonistasime teekonna graafiku kujul. Eelkõige tundsime huvi emotsionaalse reaktsiooni vastu, mis kaasnes püüdlusega saavutada uurimisrühma juhi positsioon. Seega palusime inimestel intervjuu alguses joonistada oma teekond graafiliselt. Horisontaaltelg kujutas aega doktoriõppe lõpetamisest esimese stipendiumi saamiseni uurimisrühma juhina ning vertikaaltelg emotsionaalseid kõrg- ja madalhetki sellel teekonnal. Osalejad täitsid selle ülesande väga kiiresti sageli kulus neil selleks vähem kui paar minutit -, mis näitab, et kogemuse kajastamine on üsna spontaanne. Järeldasime, et see ülesanne on intuitiivselt tähenduslik, ning intervjuu edenedes ja muude oluliste vahejuhtumite esile kerkides said nad seda joonist redigeerida. (Kõnealusest uuringust pärit teekonna joonise näidis on esitatud lisas 2.)

- Samuti oleme oma pikiuuringu intervjuudes kasutanud kaarte. Näiteks selleks, et saada konkreetne pilt seostest, mida osalejad tajusid a) isiklike suhete, b) tööalase tegevuse ja c) emotsioonide vahel, palusime intervjueeritavatel füüsiliselt paigutada kaardid nii, et need omavahel suhestuksid, samal ajal kirjeldasid nad asjaomase lävimise laadi. Soovi korral võisid nad lisada mis tahes uusi kaarte. Intervjuu lõpus jäädvustati tulemus fotona. Üldkokkuvõttes järeldasime, et narratiivide kogumisel on meie kui uurijate käsutuses üsna arvukaid strateegiaid ja mingis mõttes piirab võimalusi vaid meie enda kujutlusvõime.

Kuigi meie protokollide ülesehitus on andmete kogumise korduvate tsüklite jooksul olnud suhteliselt järjepidev, oleme teinud neisse väiksemaid muudatusi vastavalt ilmsiks tulnud leidudele ning selleks, et liigendada kontrollteemasid ja esilekerkivaid küsimusi. Peale selle on ka küsitud teabe liik rolliti (doktorant, doktorikraadiga akadeemiline töötaja või doktorikraadiga kutsetöötaja) olnud järjepidev, kuid iga protokolli valikud ja sõnastus on mõnevõrra erinevad, et need sobituks rolliga. Need versioonid edastatakse, täidetakse ja saadetakse tagasi elektrooniliselt, mis hõlbustab geograafiliselt kaugemal viibivate inimeste osalemist, ent ühtlasi tähendab see, et me ei saa vahendada osalejate vastuseid samal viisil kui intervjuude puhul.

\section{Narratiiv ja andmete esitamine analüüsis}

Võttes arvesse naturalistlikku käsitlusviisi, keskendume üksikisiku enda esitatud lugude idiosünkraatilistele elementidele (mitte jagatud elementidele, nagu sotsiaalkultuurilise käsitluse korral). Meie eesmärk on mõista asjaomase inimese kogemusi ja tema tõlgendust neist oma isiklike plaanide elluviimisel (või nende läbikukkumisel). Just siinkohal on ehk kõige 
täpsemalt näha, kuidas narratiiv erineb muudest kvalitatiivsetest meetoditest. Samamoodi nagu paljud muud kvalitatiivsed meetodid, on ka see keskendunud siiski kontekstis tehtavale analüüsile, mis võimaldab arvestada laiemaid asjaolusid, mille taustal iga narratiiv on koostatud (Juzwik, 2006). Seega võtame enda töös arvesse näiteks majanduskriisile eelnevat või järgnevat ajavahemikku ning geograafilist asukohta (Kanada, Ühendkuningriik, Euroopa), mis asetab kogutavad andmed konteksti.

Analüüsi esimese sammuna koostame iga osaleja juhtumi kohta narratiivi, mida käsitame ühe andmete esitamise vormina (Miles \& Huberman, 1994) ja mida saab kasutada lisaanalüüsides. Seejärel loeme iga osaleja andmed uuesti üle (narratiivi analüüs), et luua madala järeldustasemega kõikehõlmav narratiiv, milles säilib üksikisiku hääl (Coulter \& Smith, 2009). Teisisõnu jutustame osaleja kogemused ümber (sageli kasutades otseseid lühitsitaate) (Sfard \& Prusak, 2005), kuid säilitame narratiivi elemendid: sündmustevahelised seosed, aja möödumise ja isiku eesmärgid. Meie peamine eesmärk selles protsessis on anda üksikisiku lugu edasi nii hästi kui võimalik, segamata sellesse oma tõlgendust ja tutvudes samal ajal iga üksikjuhtumiga. (Pikiuuringutes koostatakse selliseid juhtumite kokkuvõtteid igal aastal.)

Kui kõik individuaalsed analüüsid, mille põhjal tehakse juhtumite kokkuvõtted, on koostatud, asume teise tasandi analüüside juurde. Just siinkohal esitame neist lugudest oma tõlgenduse. Selleks otsime inimeste lugudes sarnasusi ja erinevusi, et neid põhjalikumalt uurida. Kui osalejaid oleks vähem, pakuks analüüsi teine tasand vähem võimalusi, sest mida suurem on osalejate arv, seda suurem on potentsiaal näha nii kogemuste mitmekesisust kui ka jagatud tähenduste seaduspärasusi. Nii nagu muude kvalitatiivse analüüsi meetodite puhul, kasutame ka praegusel juhul tekkivaid (ja mõnikord varem kindlaksmääratud) kodeerimisskeeme ning pidevat võrdlust ja juhtumite negatiivset analüüsi koos kaasnevate menetlustega, et tagada uuringu usaldusväärsus (Miles \& Huberman, 1994). Võimaluse korral kaasame selle protsessi eri etappidesse teised meeskonnaliikmed.

\section{Narratiivi koostamine ja esitamine aruannetes}

Nagu eespool märgitud, soovime narratiiviuuringuid tehes tagada, et tähelepanu püsiks üksikisikul, seda mitte üksnes analüüside koostamisel, vaid ka seoses leidude esitamise viisiga. Seega oleme kulutanud märkimisväärselt palju aega selleks, et töötada välja erinevad loomingulised moodused osalejate narratiivide uuesti esitamiseks ja uuesti koostamiseks viisil, mille puhul säilib esitatavate andmete individuaalsus, kuid tulevad selgelt 
välja ühised seaduspärasused kogemustes. Probleem seisneb selles, kuidas säilitada inimeste elude terviklikkus ja keerukus aruannetes, mille pikkus on sageli piiratud 5000-7000 sõnaga. Erinevalt muudest kvalitatiivsetest meetoditest loome seega lühipildid, et kajastada üksikisiku kogemuste mitmetahulisust. Selliste lühipiltide pikkuseks võib olla 100-350 sõna (vt lisa 3 näide 1 artiklis kasutatud lühipildi kohta). Võimaluse korral lisame töösse kõik analüüsi jaoks vajalikud lühipildid, aga kui see ei ole võimalik, siis valime välja tüüpilised näited. Kuna analüüsi teine tasand hõlmab üksikisikuid ühendavate seaduspärasuste otsimist, siis oleme juhul, kui soovime selliseid seaduspärasusi rõhutada, kasutanud lisaks vormindamist, et lugejal oleks hõlpsam neid näha (vt lisa 3 näide 2 kolme lühipildi kohta, mille puhul karjääriotsuste tegemine on sarnane; seda kasutas McAlpine oma ilmuvas töös).

Tulemuste esitamisel ei kasuta me peaaegu kunagi osalejate tsitaate eraldiseisvalt, sest see looks kehatu hääle, mis ei väljendaks asjaomase avalduse tegemise isiklikku konteksti ja tähendust. Kui me tsitaate kasutame, on need esitatud koos lühikese ülevaatega või võimaluse korral katkendina isiku esitatud andmetest, mis on töös juba lühipildina ära toodud. Nagu teised interpreteerivad uurijad, loodame ka meie, et meie uuringute aruanded on tõepärased, sidusad, veenvad, kasulikud, autentsed, usaldusväärsed ja suure kõlapinnaga (Coulter \& Smith, 2009; Pinnegar \& Daynes, 2007).

\section{Eetikaküsimused}

Oleme teadlikud sellest, et tulemuste esitamiseks lühipiltide koostamisel tuleb olla ettevaatlik, sest nende lühiduse tõttu oleme sunnitud palju teavet välja jätma. Lisaks soovime mitmesuguste kogemuste koondamisel lugejale tähenduslikesse, suhteliselt sidusatesse narratiividesse vältida neile sellise tähenduse omistamist, mis algsetes narratiivides puudus.

Meie pikiuuringute puhul tekib mitu eetikaküsimust, mille tõstatumine ühekordsetes uuringutes on vähem tõenäoline. Eesmärk on tagada, et meie suhe osalejatega hõlmaks hoolivuse eetikat (Tronto, 1995), sest aja jooksul saame isiku kohta privilegeeritud intiimseid teadmisi - nagu üks osaleja ütles: „Te tunnete mu elu.” Kõige silmapaistvam näide sellise hoolivuse eetika kohta on asjaolu, et me loeme iganädalased tegevuspäevikud läbi niipea, kui need saabuvad, püüdes tähele panna mis tahes probleemidele osutavaid märke. Sellisel juhul koostab kohalik meeskond osalejatele soovitused kasulike materjalide kohta, viidates näiteks institutsionaalsele nõustamisele või asjakohasele poliitikale. Ka e-kirjavahetuses osutame sageli hiljutistele sündmustele või kogemustele, mida osalejad on maininud. 
Samamoodi nagu teised uurijad, kes kasutavad kvalitatiivseid meetodeid, oleme ka meie tulemuste esitamisel hoolikad, et tagada anonüümsus. Oleme meeskonnana kokku leppinud selles, kuidas jätta välja isiklikud andmed, mis meie arvates võivad anda võimaluse isiku tuvastamiseks, näiteks kasutades sõna partner sõnade mees/naine asemel või laps/lapsed sõnade poeg/tütar asemel ning esitades geograafilise asukohana ainult riigi või mandri. Pikiuuringute puhul on see eriti oluline, sest üksikisiku elu idiosünkraatilise kronoloogia esitamine mitme aasta vältel teeb tema äratundmise mõnevõrra hõlpsamaks. Anonüümsuse säilitamise probleem võib olla veelgi pakilisem, kui aja jooksul üha lähedasemaks muutuva suhte tõttu esitatakse sellist teavet, mis muidu ei pruugiks paljastuda. Osalejatel on õigus soovi korral valikuliselt uuringus antud andmeid eemaldada, kuigi seda võimalust ei ole peaaegu kunagi kasutatud. Ilmselgelt põhjustab teabe väljajätmine probleeme tegeliku loo tõepärasuse tagamisel ja samal ajal anonüümsuse säilitamisel. Eelmises lõigus märgitule lisaks võime muuta osaleja jutustuse üksikasju, säilitades samas kogemuse olemuse.

Peale selle, et me jätame aruannetest välja isiklikud andmed, koostame pikiuuringute puhul iga inimese narratiivist ka kaheleheküljelised madala järeldustasemega kokkuvõtted, kui inimese osalemine uuringus jõuab lõpule. Saadame need kõikidele osalejatele koos järgmise palvega:

"Soovime Teie abi teabe tõelevastavuse tagamisel. Palun vaadake kokkuvõte läbi ja andke meile teada, kas on midagi, mis Teie arvates a) on välja jäänud, b) on vale või c) võimaldab Teie isiku ära tunda."

Tunneme heameelt selle üle, et üldiselt on neid lugusid väga vähe muudetud. Seega usume, et oleme leidnud suhteliselt usaldusväärse viisi anonüümsuse tagamiseks.

\section{Narratiivi kasutamise eelised ja puudused}

Narratiivid on oma olemuselt eksplitsiitselt tegijakesksed ning näitavad, kuidas üksikisikud püüavad oma soove, lootusi ja kavatsusi nii oma elu struktureeritud elementide kui ka ootamatuste vahel laveerides ellu viia. Samamoodi nagu mõnes teises sotsiaalteaduste valdkonnas, on ka minu tegevusalal eelistatud süsteemset või struktureeritud vaatenurka, mis rõhutab, kuidas organisatsioon ja ühiskond suunavad üksikisikute õppimist ja arengut (Antony, 2002). See on tähendanud seda, et individuaalseid jõupingutusi end ise motiveerida ja oma tegevust juhtida on kaldutud pisendama ning individuaalsed erinevused on jäänud märkamata. Narratiivne 
käsitlusviis võib struktureeritud käsitlust täiendada, pakkudes alternatiivset vaatenurka. Nagu on märkinud Elliot (2005, lk 125), välditakse narratiividega „nii essentsialistliku kui ka konstruktivistliku enesekäsituse äärmusi”. Veel üks eelis on see, et uurija koostatud narratiivid on lugejale hõlpsalt mõistetavad, seega saab uuringu tulemusi pedagoogiliselt kasutada selleks, et pakkuda - minu puhul doktorantidele - alternatiivseid võimalusi oma tuleviku kavandamisel.

Nii nagu kõikidel metoodikatel, on ka sellel omad puudujäägid. Tuleb arvesse võtta, et narratiivis konstrueeritud identiteet on vaid üks aspekt tegevuse kaudu loodud identiteedist. Sellisena asendab see tegevusega tegelemist ning tähtis on vältida identiteedi esemestamist (keegi „on identiteet”) ja rõhutada selle asemel, et keegi „tegutseb identiteedina” (Sfard \& Prusak, 2005).

Samuti tähendab narratiivide loomuomane struktuur (uuritav subjekt koostab sidusa ülevaate kogemusest) seda, et narratiivid „väljenduvad sageli viisil, mille puhul jäetakse tähelepanuta mis tahes kõikehõlmav määramatuse, osalisuse ja keerukuse tunne" (Taylor, 2008, lk 29). Pealegi kajastavad osalejate narratiivid vaid piiratud arvu kogemusi, mida meie, uurijad, kasutame seejärel ligilähedase sidusa loo koostamiseks. Seega peab uurija pöörama tähelepanu teabele, mis jääb inimese loost välja, aga ka eri lugude ebakõladele või lugudes sisalduvate kahtluste või ümbernurgaütlemiste tähendusele. (Mida suurem on uuringus osalejate arv, seda rohkem erinevusi kogemuste kujutamisel loomulikult esineb ja seda enam võib uurija tunda, et ta on kajastanud mitmekesiseid kogemusi ja tähendusi.) Narratiivides kaldutakse ka rõhutama kogemuste isiklikult tähendusrikkaid tõlgendusi ja võidakse jätta tähelepanuta laiemad struktuursed mõjud (Walker, 2001). Selle probleemi lahendamiseks soovitab Elliott (2005) uurijatel tutvuda mahukate asjakohaste andmebaasidega, näiteks rahvaloenduse andmetega, mis pakuvad lugudele konteksti.

\section{Narratiivi kui metoodika väärtus}

Minu eesmärk oli muuta narratiivimetoodikaga (praegusel juhul naturalistliku käsitlusviisiga) seotud mõttekäigud, protsessid ja menetlused läbipaistvamaks ning tekitada seeläbi teisteski tahtmine narratiivi lähemalt uurida ja kasutada. Nagu märgivad Pinnegar ja Daynes (2007, lk 28), jääb narratiiv jätkuvalt ,akadeemilise töö ääremaadele”. Sellest hoolimata pakub see usaldusväärseid metoodilisi vahendeid uurijale, kes soovib pöörata suuremat tähelepanu inimkogemuste erinevustele ning kes leiab 
sobiva kooskõla oma epistemoloogilise vaatenurga ja narratiiviuuringutega kaasnevate mitmesuguste metodoloogiliste käsitlusviiside vahel.

\section{Kasutatud kirjandus}

Alexander, P., Harris-Huemmert, S., \& McAlpine, L. (2014). Tools for reflection on the academic identities of doctoral students. International Journal for Academic Development, 19(3), 62-173. doi: http://dx.doi.org/10.1080/1360144X.2013.817333

Antony, J. S. (2002). Reexamining doctoral student socialization and professional development: Moving beyond congruence and assimilation orientation. In J. C. Smart (Ed.), Higher education: Handbook of theory and research (Vol. 17, pp. 349-380). Dordrecht: Kluwer. doi: http://dx.doi.org/10.1007/978-94-010-0245-5_8

Archer, M. S. (2003). Structure, agency and the internal conversation. Cambridge: Cambridge University Press. doi: http://dx.doi.org/10.1017/CBO9781139087315

Bagnoli, A. (2009). Beyond the standard interview: The use of graphic elicitation and arts-based methods. Qualitative Research, 9(5), 547-570. doi: http://dx.doi.org/10.1177/1468794109343625

Billet, S., \& Somerville, M. (2004). Transformations at work: Identity and learning. Studies in Continuing Education, 26(2), 309-326. doi: http://dx.doi.org/10.1080/158037042000225272

Buckingham, D. (2009). „Creative” visual methods in media research: Possibilities, problems and proposals. Media Culture Society, 31(4), 633-652. doi: http://dx.doi.org/10.1177/0163443709335280

Churchman, D., \& King, S. (2009). Academic practice in transition: Hidden stories of academic identities. Teaching in Higher Education, 14(5), 507-516. doi: http://dx.doi.org/10.1080/13562510903186675

Connelly, F. M., Clandinin, D. J., \& He, M. F. (1997). Teachers' personal practical knowledge on the professional knowledge landscape. Teaching and Teacher Education, 13(7), 665-674. doi: http://dx.doi.org/10.1016/S0742-051X(97)00014-0

Coulter, C. A., \& Smith, M. L. (2009). The construction zone: Literary elements in narrative research. Educational Researcher, 38(8), 577-590. doi: http://dx.doi.org/10.3102/0013189X09353787

Creswell, J. W. (2007). Qualitative inquiry and research design: Choosing among five approaches (2nd ed.). Thousand Oaks, CA: Sage.

Cumming, J. (2009). The doctoral experience in science: Challenging the current orthodoxy. British Educational Research Journal, 35(6), 877-890. doi: http://dx.doi.org/10.1080/01411920902834191

Elliott, J. (2005). Using narrative in social research: Qualitative and quantitative approaches. London: Sage.

Holley, K. A., \& Colyar, J. (2009). Rethinking texts: Narrative and the construction of qualitative research. Educational Researcher, 38(9), 680-686. doi: http://dx.doi.org/10.3102/0013189X09351979

Hopwood, N., \& Paulson, J. (2012). Bodies in narratives of doctoral students' learning and experience. Studies in Higher Education, 37(6), 667-681. doi: http://dx.doi.org/10.1080/03075079.2010.537320 
Juzwik, M. (2006). Situating narrative-minded research: A commentary on Anna Sfard and Anna Prusak's „Telling identities”. Educational Researcher, 35(9), 13-21. doi: http://dx.doi.org/10.3102/0013189X035009013

McAlpine, L. (2014). Post-PhD trajectories: Desperately seeking careers? Higher Education Review, 47(1), 4-35.

McAlpine, L. (2016). Becoming a PI: Shifting from „doing” to „managing” research. Teaching in Higher Education, 21(1), 49-63. doi: http://dx.doi.org/10.1080/13562517.2015.1110789

McAlpine, L. (in press). Post-PhD non-academic careers: Intentions during and after degree. International Journal for Researcher Development.

McAlpine, L., \& Amundsen, C. (2015). Early career researcher challenges: Substantive and methods-based insights. Studies in Continuing Education, 37(1), 1-17. doi: http://dx.doi.org/10.1080/0158037X.2014.967344

McAlpine, L., Amundsen, C., \& Turner, G. (2013). Tracking experience over time: Epistemological issues and methodological challenges. In J. Huisman \& M. Tight (Eds.), Theory and Method in Higher Education Research (pp. 97-114). London: Routledge. doi: http://dx.doi.org/10.1108/S1479-3628(2013)0000009009

McAlpine, L., Amundsen, C., \& Turner, G. (2014). Identity-trajectory: Reframing early career academic experience. British Educational Research Journal, 40(6), 952969. doi: http://dx.doi.org/10.1002/berj.3123

Miles, M. B., \& Huberman, A. M. (1994). Qualitative data analysis (2nd ed.). Thousand Oaks, CA: Sage Publications.

Pinnegar, S., \& Daynes, J. G. (2007). Locating narrative inquiry historically: Thematics in the turn to narrative. In D. J. Clandinin (Ed.), Handbook of narrative inquiry: Mapping a methodology (pp. 1-34). Thousands Oaks, CA: Sage. doi: http://dx.doi.org/10.4135/9781452226552.n1

Riessman, C. K. (2008). Narrative methods for the human sciences. Los Angeles, CA: Sage.

Sfard, A., \& Prusak, A. (2005). Telling identities: In search of an analytic tool for investigating learning as a culturally shaped activity. Educational Researcher, 34(4), 14-22. doi: http://dx.doi.org/10.3102/0013189X034004014

Taylor, P. (2008) Being an academic today. In R. Barnett \& R. Di Napoli (Eds.), Changing identities in higher education: Voicing perspectives (pp. 27-39). London: Routledge.

Tronto, J. C. (1995). Care as a basis for radical political judgments. Hypatia, 10(2), 141-149. doi: http://dx.doi.org/10.1111/j.1527-2001.1995.tb01376.x

Walker, M. (2001) Engineering identities. British Journal of Sociology of Education, 22(1), 75-89. doi: http://dx.doi.org/10.1080/01425690020030792

Ylijoki, O.-H. (2001). Master's thesis writing from a narrative approach. Studies in Higher Education, 26(1), 21-34.

doi: http://dx.doi.org/10.1080/03075070020030698 
Lisa 1. Täidetud päeviku näidis

Allpool on esitatud loodusteaduste doktorandi iganädalase päeviku transkriptsioon. Üliõpilase vastused küsimustele on toodud kursiivis; neid on mõnevõrra toimetatud, et säilitada anonüümsus ja teksti lühendada.

1. Sel nädalal tegelesin ligikaudu_40_tundi akadeemilise tööga, mis lõppkokkuvõttes toetab mu doktoritöö valmimist.

2. Palun märkige tegevused, millele see aeg kulus. (Märkige X kõikide kehtivate väidete ette ja esitage üksikasjad.)

a) X Lugemine ____ Veetsin palju aega LaTeXit (avatud allikatega dokumendi koostamise süsteemi) käsitlevaid veebilehti lugedes, seejuures tegin endale selgeks, kuidas seda kasutada oma väitekirja esimese peatüki / teadusartikli kirjutamiseks.

b) Kirjanduse läbivaatamine

c) Eetikaküsimusi puudutava heakskiidu saamine

d) Üldeksamiks valmistumine

e) Uuringuettepaneku ettevalmistamine

f) Välitööde ettevalmistamine

g) X Andmete kogumine Sel nädalal kulutasin enamiku ajast proovide töötlemisele gaasikromatograafis, et nende põhjal andmeid koguda. Nädala jooksul töötlesin ligikaudu 80 proovi.

h) X Andmete analüüsimine ____ Kuni gaasikromatograaf proove töötles, kasutasin aega ka andmefailide organiseerimiseks ja analüüsiaruannete kirjutamiseks, et töödelda andmeid, kui need on kättesaadavad.

i) Väitekirja kirjutamine

j) X Teadusartiklite/konverentsiettekannete/aruannete kirjutamine Kirjutasin valmis enamiku metoodikat käsitlevast jaost, mis moodustab osa publikatsioonist ning millest saab ka üks peatükk mu väitekirjas.

k) Uuringu tutvustamine konverentsil/praktikumis/seminaril (kus ja mis teemal?)

1) Konverentsil/seminaril/praktikumis osalemine (kus ja mis teemal?)

m) X Kohtumine/vestlemine/kirjavahetus juhendaja(te)ga Mul oli tunniajaline iganädalane kohtumine juhendajaga, et arutada töö edenemist ja tähtaegu. Ta oli mult selleks nädalaks palunud metoodikaosa, millest ma jõudsin enamiku valmis. Jätkuvalt on esmatähtis viia lõpule andmete kogumine, et saaksin kätte tulemused, ja alustada ülejäänud töö kirjutamist.

n) Kohtumine/vestlemine/kirjavahetus teiste teaduritega

o) X Muu (palun täpsustage, nt rahastamistaotlused) ____ Kulutasin umbes tunni, et tutvuda konverentsiga, millel sooviksin osaleda, ning selgitada välja selle kulud, koostada eelarve ja leida rahastamisvõimalusi. Järgmise paari nädala jooksul on mul vaja täita paar reisitoetuse taotlust, kuid sellega ei ole hetkel veel vaja tegeleda. 
3. Sel nädalal tegelesin veel järgmisega

a) Täiskohaga töötamine mitteakadeemilisel tööl

b) X Osalise tööajaga töötamine mitteakadeemilisel tööl 4 h: komitee töö ja kohtumise korraldamine seoses [siin] peetava teaduspoliitikakonverentsiga.

c) X Osalise tööajaga osalemine teadusuuringutes, mis ei ole seotud minu doktoritööga (kui jah, siis kelle või mille jaoks) Kulutasin paar tundi EndNote'i andmebaasi korrastamiseks lepingulise tööna. See on viimane ülesanne, mille eest ma selles projektis vastutan, seega püüan sellega ühele poole saada, kuigi teema on minu uuringu seisukohast asjakohane, isegi kui ülesanne ise mu väitekirja kirjutamist otseselt ei toeta.

d) Õpetaja või juhendajana töötamine (kui jah, siis palun täpsustage, mis valdkonnas ja kus)

e) Akadeemilise komitee koosolekul osalemine (kui jah, siis mis komiteega oli tegemist)

f) X Praktikumides, tundides, seminaridel või loengutel osalemine (kui jah, siis kus ja mis teemal) 2: statistikateemaline praktikum

g) (Laste, abikaasa, muude sugulaste jt) hooldamine

h) Muu (palun loetlege kõik tegevused, mida Te oluliseks peate, nt spordi-/ vabaajategevus, vabatahtlik töö, ühiskondliku elu üritused, reisimine)

4. Palun kommenteerige/täpsustage, kuidas Te sel nädalal oma aega kasutasite.

Kuigi enamiku ajast veedan gaasikromatograafi näidiseid sisestades, on selle juures meeldiv see, et kahe näidise vahel tuleb seitse minutit oodata. Tavaliselt panen gaasikromatograafi kõrvale üles oma sülearvuti, et kromatograafi järel oodates muud tööd teha. See tähendab, et proovide peale kulub veidi kauem aega kui otseselt vajalik (mõnikord tähelepanu hajub ja ma ootan proovide vahel kauem kui tarvis), kuid samuti tähendab see, et töö ei ole nii igav ja ma suudan palju rohkem ära teha. Või vähemalt mulle tundub nii.

5. Sel nädalal lävisin järgmiste inimestega, kes mind mu doktoritöös aitavad.

a) X Minu uurimisrühma/-meeskonda kuuluv üliópilane Saatsin meili teel tehnilised küsimused LaTeXi kohta mõnele meie laboris töötavale kolleegile, kes on seda samuti kasutanud.

b) Teine üliõpilane (teised üliõpilased) (kui jah, siis mis erialalt)

c) X Minu juhendaja ____ Kohtusime sel nädalal, et arutada töö edenemist ja tähtaegu.

d) Programmijuht

e) Teised professorid (kui jah, siis mis erialalt)

f) Raamatukogutöötajad

g) X Teised ülikooli töötajad (nt sekretärid, personalitöötajad või arvutispetsialistid) (palun täpsustage). Küsisin mõnelt arvutispetsialistilt varundamisvõimaluste kohta ja kooskõlastasin tehnilist tuge pakkuvate töötajatega mikroskoobikaamerate jaoks tarkvara paigaldamist labori arvutitesse.

h) Perekond

i) Sõbrad

j) Teised (palun täpsustage) 
6. Sel nädalal tunnen ma oma juhendaja(te)ga seoses järgmist (palun tähistage Xiga ÜKS vastus, mis teie sellenädalast kogemust kõige paremini iseloomustab):

a) X Ei vajanud abi_____ Ma juba teadsin, mida ma tegema pean, ning mul oli selleks lihtsalt omaette olemise aega vaja. Kuigi meil oli kohtumine, toimus see gaasikromotograafi kõrvalruumis, seega jätkasin samal ajal proovide töötlemist ja see ei seganud oluliselt mu uurimistegevust.

b) Vajasin abi

c) Ei soovinud abi

d) Soovisin abi

KUI soovisite või vajasite oma juhendajalt abi, siis palun vastake järgmisele küsimusele, kui mitte, siis palun jätkake küsimusega 8 .

7. Kui soovisite või vajasite abi, siis mis probleem Teil oli?

a) Miks Teile tundus, et juhendaja oleks parim isik, kes saab Teid aidata?

b) Kas saite abi, mida vajasite?

c) Kui ei, siis palun selgitage, miks see Teie arvates nii läks.

d) Kas saite abi, mida vajasite, kelleltki teiselt kui oma juhendajalt? Kes see isik (need isikud) oli(d)?

8. Sel nädalal olid minu akadeemilise tegevuse edenemise seisukohast kõige olulisem(ad) isik(ud) (positiivselt või negatiivselt):

a) Internet: uurisin veebist palju LaTeXi kohta. Laboritööd tegin suuresti iseseisvalt.

b) Nad olid olulised, sest______ teiste teadlaste avaldatud elektrooniline materjal andis mulle konkreetset teavet, mida ma vajasin, ning aitas mul lahendada probleeme ja liikuda oma eesmärkide poole.

9. Kui toimus mingi oluline sündmus või saite mõne sellise olulise kogemuse osaliseks, mille puhul tundsite end teadlasena või akadeemilisse ringkonda kuuluvana, siis palun rääkige sellest.

Tundsin end teadlasena kogu laboris veedetud aja jooksul, eriti óppides kasutama müstilist (kuid tõhusat!) dokumentide koostamise süsteemi tehnilise teksti kirjutamiseks (LaTeX). Kirjutamisprotsessi alustamine oli samuti oluline, sest see on tavaliselt kõige raskem. [KUSTUTATUD TEKST]

Miks oli see sündmus või kogemus oluline? _____ Tulemuse nägemine paneb mind tundma, et olen midagi saavutanud, olenemata sellest, kui väike see tulemus on. Samuti meenus mulle, kui väga ma kirjutamist naudin, ja ma olin veidi üllatunud sellest, kui motiveeritud ma olin jätkama mõnikord kirjutamist ka hilisõhtuti, olles saanud üle esialgsest vastumeelsusest tööga alustada. [KUSTUTATUD TEKST]

10. Kui toimus mingi oluline sündmus või saite mõne sellise olulise kogemuse osaliseks, mille puhul Te ei tundnud end teadlasena või akadeemilisse ringkonda kuuluvana, siis palun rääkige sellest. Eelmise küsimuse vastuses kirjeldatud kohtumise alguses oli mul tunne, et ma olen akadeemilisest ringkonnast välja jäetud. Selle tunde tekitasid mõned kohtumisel viibinud isikud, kes viitasid teaduskonna ja muude institutsioonide „ressurssidele” ning üliõpilaste „vajadustele”. Juhtisin kiiresti nende tähelepanu sellele, et minu arvates ei ole see mõttetu vahetegemine, ja 
sellele, kui palju saavad kraadiõppurid vastastikusesse õppimisse tegelikult panustada. [KUSTUTATUD TEKST]

Miks see kogemus Teis selliseid tundeid tekitas?

11. Kas on midagi, millele Te oleksite pidanud sel nädalal keskenduma või soovinud keskenduda, kuid ei saanud seda teha?

a) Millest see tulenes?

12. Palun täpsustage probleeme, millega Te sel nädalal kokku puutusite. Analü̈̈side uurimine, millega ma tegelen, paistab võtvat rohkem aega, kui olin selleks kavandanud. See on nii enamiku asjadega. Iga proovi peale kulub kokku vähemalt kaheksa minutit, kuid keeruline on pidevalt produktiivselt töötada ja sisestada proove piisavalt kiires tempos, et suuta päeva jooksul nii palju ära teha, et ma end produktiivsena tunneksin. Mulle meeldib seada endale igapäevaseid eesmärke, kuid nende täitmiseks pean mõnikord väga kaua laboris viibima ning see häirib mu söömis- ja magamisharjumusi, mistõttu ma olen kurnatud ja kehvas tujus. Seda kuni nädalalõpuni, mil hakkan oma üldiste edusammude üle suuremat rahulolu tundma. Samuti hakkasin õppima uut teaduslike tekstide kirjutamise süsteemi (LaTeX). Olen tuttav selle üldise põhimõttega, kuid mitte üksikasjadega, mida ma vajan soovitu saavutamiseks.

a) Mida Te tegite, et püüda neid lahendada?

Nädalavahetuseti teen palju sü̈̈a, et mul oleks nädala sees toit olemas, mis võimaldab mul laboris rohkem aega veeta, kuna kodusteks toimetusteks vajan vähem aega.

Õppimisega seotud vajaduste täitmiseks otsisin internetist materjali ja lugesin seda.

13. Mil määral Te tunnete, et suudate saavutada tasakaalu töö ja eraelu vahel? Mis küsimused ja/või strateegiad aitavad seda tasakaalu saavutada (või takistavad seda)? Arvan, et sel nädalal ei olnud mu töö- ja eraelu tasakaal eriti paigas, kuna enamik aega kulus tööle. See on paljuski tingitud lähenevatest tähtaegadest ja sellest, et nendest kinnipidamiseks on vaja veel palju tööd teha. Ma leian, et osaliselt tuleneb see sellest, et oma doktorantuuri alguses kulutasin liiga palju aega muu tegevuse peale, või sellest, et mul puudus kindel suund ja ma veetsin liigselt aega otsuste tegemiseks, selle asemel et pü̈̈da oma tähtaegadest kinni pidada. Teisalt veetsin puhkuse ajal terve kuu pigem eraelu kui tööga tegeledes, nii et kokkuvõttes on need ehk tasakaalus, kuigi mitte lühiajalises perspektiivis. Tagasi vaadates oleksin võinud läbivalt parema tasakaalu saavutada, kuid mõnikord on keeruline motivatsiooni säilitada.[KUSTUTATUD TEKST]

Täname Teid! 
Lisa 2. Teekonna joonise näidis

Allesitatud teekonna joonis lasti koostada intervjuu alguses, et osaleja keskenduks oma kogemustele teel doktorikraadi omandamisest esimese stipendiumi saamiseni juhtteadlasena (McAlpine, 2016). Siin on kujutatud Romeo kogemusi, kuid anonüümsuse tagamiseks on joonist muudetud. See joonis oli aluseks intervjuu esimesele osale, mille käigus täpsustas osaleja oma kirja pandud kogemusi.

\section{Teekonna joonis}

Palun märkige graafikule oma esimese stipendiumi saamisega seotud kogemuse kõrg- ja madalpunktid alates doktorantuuri lõpetamisest kuni stipendiumi saamiseni. Palun täpsustage kõrg- ja madalpunkte ning lisage kõik asjakohased kuupäevad.

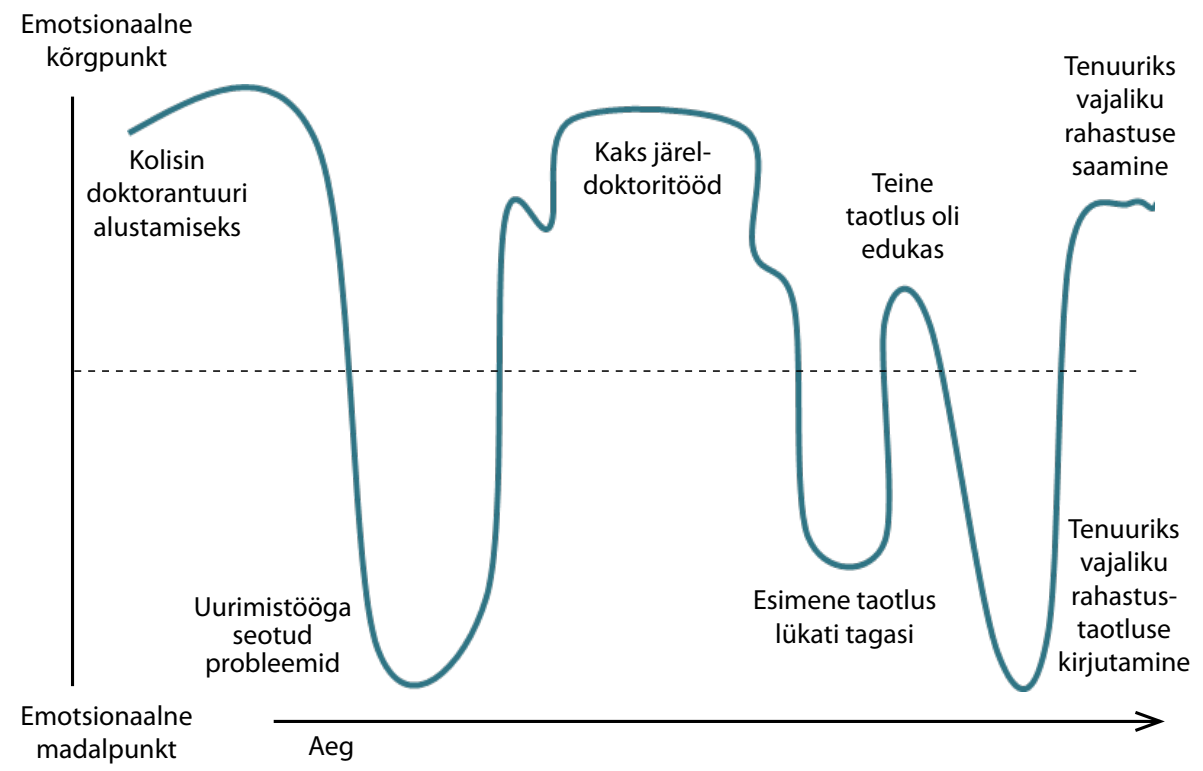


Lisa 3. Uurija koostatud narratiivi näited

Kõikide alljärgnevate näidete aluseks on narratiivid, mille on esitanud üks uuringus osaleja (kes palub end nimetada KSiks). Esimese puhul on tegemist traditsioonilisema versiooniga uurija ümberkujundatud narratiivist, mis on avaldatud uurimistöös, ja teise koostasime kasutamiseks oma veebilehel.

1. näide. Uurimistöös sisalduv madala järeldustasemega lühipilt (McAlpine et al., 2014)

KS, 29, sotsiaalteadused/SS, töötas mitmes USA vabaühenduses, enne kui tuli Ühendkuningriiki, et omandada teistsuguseid kogemusi. Pärast ühes ülikoolis magistrikraadi saamist läks ta lühiajalise lepingu alusel teadurina üle teise ülikooli. Ta arvas, et võiks läbida doktorantuuri, sest talle meeldis teadustöö ja ta taipas, et selle jätkamiseks vajab ta doktorikraadi. Samal ajal tajus ta, et tema isiklik elu jääb tagaplaanile, ning ta mõtles USAsse naasmisele, et olla oma pere lähedal. Siiski mõistis ta, et Ühendkuningriigis loodud akadeemiline võrgustik võib talle USAs uusi karjäärivõimalusi pakkuda. Temast sai sama teaduskonna doktorant ja teatavas mõttes nõrgenes tema staatus, ent samas sai ta hulga lähedasi kolleege. Alguses oli tal probleeme oma juhendajaga ning ta kahetses, et ei olnud programmi valikut laiemalt kaalunud. Seejärel haigestus raskelt KSi pereliige, mistõttu võttis ta doktorantuurist akadeemilise puhkuse ja läks pikaks ajaks tagasi USAsse. Naastes jätkas ta programmi uue eesmärgitunnetusega ja viis lõpule oma välitööd, kuigi alguses said tema edusammud ajutise tagasilöögi järjekordse haigestumise tõttu perekonnas. Pärast naasmist alustas ta tööd õpetajana, mida ta naudib, samuti osaleb ta väitekirja kirjutamise kõrvalt üliõpilasajakirja väljaandmises. Ta on küll suuresti pühendunud akadeemilisele karjäärile, kuid samavõrra soovib ta töötada lastega ja muretseb selle üle, kuidas mõlemaga toime tulla. Olles hiljuti püsisuhet alustanud, tunnistab ta, et kui see jääb kestma, kavandab ta oma tuleviku enda ja oma partneri huvidest lähtudes, olgu siis Ühendkuningriigis või USAs. 


\section{2. näide. Vorming, mis näitab seaduspärasusi karjääriotsuste tegemisel pika aja jooksul (McAlpine, ilmumas)}

Kõigi kolme lühipildi ülesehitus on ühesugune ja näitab samu seaduspärasusi seoses kavatsusega saada doktorikraad, et naasta oma erialale ja seal tõhusamalt töötada:

- varjunimi, päritolu, eelnev töökogemus, isiklikud suhted, kraadiõppe põhjused, algsed karjääriplaanid (Calibri)

- tegelemine doktoritööga / akadeemilise tööga, plaanide muutumine pärast doktorikraadi omandamist (Times New Roman)

- kraadiõppele järgnevad kogemused (Arial Narrow)

Ladina-Ameerikast pärit Daniel, kelle jaoks inglise keel ei ole emakeel, töötas keskkonna valdkonnas ning kolis koos oma partneri ja lapsega doktorikraadi saamiseks teise riiki. Pärast kraadi omandamist kavatses ta oma eriala juurde tagasi pöörduda, leides, et kraad annaks talle olulisi kogemusi ja lisaks tõsiseltvõetavust.

Kraadiõppe jooksul otsis ta võimalusi töötada nõustaja ja konsultandina, et luua ametialaseid võrgustikke, kuid ei avaldanud ega esitlenud oma töid. Aja möödudes suurendas ta õpingute rahastamiseks oma töökoormust, mistõttu õpingute lõpetamiseks kulus rohkem aega. Enne kraadiõppe lõpetamist pöördus ta viisaprobleemide tõttu koos perega tagasi oma koduriiki. Tänu kraadiõppe ajal tehtud nõustamistööle pakuti talle õpingute lõppetapis tööd ühes organisatsioonis, kus ta oli töötanud konsultandina.

Danieli jaoks on doktoriõppe käigus saadud kogemustel tema praeguses eduloos täita keskne osa. Peale selle, et ta laiendas rahvusvaheliste ekspertide võrgustikku, mille teenuseid ta tänaseni kasutab, on tal välja kujunenud ka tema valdkonnas vähelevinud mõtteviis - teatav küsimustel põhinev lähenemine, mis inimestele sümpatiseerib.
Põhja-Ameerikast pärit Shannon töötas haridustöötajana, kui tema kolleeg soovitas tal taotleda üht stipendiumit, sest doktorikraad annaks talle parema võimaluse muuta haridusmaastikku ja mõjutada poliitikat. See tähendas oma kokkuhoidva pere mahajätmist ja teise riiki kolimist.

Leides, et tema teaduskonnas jagavad vähesed tema vaateid sotsiaalse õigluse küsimustes, püüdis ta leida endale mõttekaaslasi mujalt. Ta ei esitlenud ega avaldanud oma töid. Selle asemel valis ta rahulikuma töökoha, sest tundis, et akadeemiline külg tema elus on kurnav.

Ta lükkas oma tuleviku kohta otsuse tegemise edasi kuni kraadi omandamiseni ja otsis siis sellist töökohta, milles oleks ühendatud teadustegevus, poliitika kujundamine ja praktika, mis muudaks haridusmaastikku ja laseks tal pere lähedal olla. Ta leidis töö kõrgema haldustöötajana oma pere lähedal asuvas koolipiirkonnas. Töö oli aga nii intensiivne, et selle kõrvalt ei jäänud aega isiklikuks eluks, kuigi ta soovis abielluda ja lapsi saada. Talle pakuti lepingulist tööd haridusvaldkonna mittetulundusühingus, esmalt asepresidendi ja seejärel presidendina. Sellel ametikohal saab ta kujundada oma organisatsiooni ning tagada parema tasakaalu töö- ja eraelu vahel.
Ühendkuningriigist pärit Hannah kasvatas lapsi, töötades samal ajal meditsiinivaldkonnas, ning alustas doktoriõpet oma kodulinnas. Ta huvitus oma valdkonnaga seotud teadustegevusest ning kujutles, et tulevikus suudab ta ühendada meditsiinipraktika ja teadustegevuse. Hannah taipas juba varakult, et tal tuleb oma naiivsusest loobuda, akadeemilises elus enesekindlamaks muutuda ja ise oma uurimisprojekti ohjama hakata. Ta osales mitmel esitlusel, kuid ei avaldanud oma töid, sest soovis väitekirja lõpuni kirjutada. Selle lõppetapis asus ta otsima kodulähedast töökohta. Ta leidis töö ülikooliga mitteseotud tervishoiuasutuses töötajate teadussuutlikkuse suurendamise valdkonnas - tegelikult koostas ta ise oma töökirjelduse. Hannah teadis, et teadustööks raha saamiseks peab ta oma töid avaldama, ja paari aasta jooksul tegigi ta seda, püüdes samal ajal luua suhteid ülikoolis, sest tal puudus akadeemiline keskkond ning ta tundis, et tema enda teadustegevus jääb tagaplaanile. Tänu võrgustike loomisele kuulis ta töökohast ülikooliga seotud tervishoiuasutuses ja kandideeris sellele. Uus töö võimaldab tal teha teadustööd, mis talle rahuldust pakub (ta sai selleks rahalised vahendid), ja suurendada oma kolleegide teadussuutlikkust. Nüüd, mil Hannah' lapsed on täiskasvanud, loodab ta leida töö kodust kaugemal. 
3. näide. Individuaalse narratiivi alternatiivne esitamine (väljavõte) veebilehel kasutamiseks

Alljärgnev narratiiv kajastab KSi lugu (räägituna teisiti), kujutades tema elu kolme haru horisontaalteljel ja aja kulgemist vertikaalteljel. See võimaldab teha otsinguid sündmustest tema elus.

\section{Väljavõte KSi ajakavast seoses isikliku elu, töökogemuse ja tulevase karjääriga -} „minu elu kui Ameerika mäed”

ISIKLIK ELU: „Kolimine oli minu elus üsna määrava tähtsusega ettevõtmine"

Jättis maha kokkuhoidva pere Põhja-Ameerikas, et vahelduse eesmärgil Ühendkuningriiki kolida

Isiklik elu on ooterežiimil

Nägi doktorikraadis võimalust luua sotsiaalseid ja akadeemilisi võrgustikke Ühendkuningriigis

Raske haigus perekonnas; võttis puhkuse ja pöördus kuueks kuuks tagasi PõhjaAmeerikasse

Naasis Ühendkuningriiki; tagasitulek oli suur kergendus; tugevnes tema otsus seal viibida; kõige pikem aeg, mille jooksul ta oli lapsepõlvest saadik ühes kohas elanud; lootis leida abikaasa ja võib-olla lapsi saada (bioloogiline imperatiiv)

Välitööde tegemise ajal ilmnes järjekordne haigus perekonnas; õnnestus mõlemaga toime tulla
TÖÖKOGEMUS: „Õppisin mitte keskenduma ühele asjale ... tegelema eri asjadega"

Töötas paar aastat pärast

bakalaureusekraadi saamist

Omandas magistrikraadi (lõpetas 2008. aastal)

2008-2009: vahetas ülikooli, et töötada lepingulise teadlasena; nautis meeskonna koostöövaimu

2009-2010: juhendaja soovitas omandada doktorikraadi, aitas projektile rahastust leida; see ei pakkunud talle tingimata suurt huvi, vaid oli pragmaatiline otsus

Alustas doktoriõpet; töötas omaette; juhendaja oli eemalolev; kõhkles, kas otsus oli õige; üritas oma töid avaldada; sai abi teaduslepingu alusel töötavalt kolleegilt; hoo mahavôtmine teooriavõlgnevuste likvideerimiseks; aja leidmine lugemiseks (uppus kirjandusse)

Väga ebastabiilne olukord; hoog rauges

2010-2011: sai uuesti hoo sisse; kuulus meeskonda, KUID jätkuv mure seoses juhendajaga; sai abi kolleegilt; osales artikli kirjutamises. Kas tegelikult toimub edasiminek? Vajadus leida lugemise kaudu oma teema

2011-2012: välitööd PõhjaAmeerikas; väga keeruline korraldada; väga üksildane; akadeemilisest keskkonnast eraldatud
MÕTTED

KARJÄÄRI KOHTA:

Uurimistöö inspireerib, tõstab tuju

Akadeemiline võrgustik Ühendkuningriigis kasvab, kuid PõhjaAmeerika oma kahaneb; tundis, et on teadurina justkui variisik

Ebakindlus tuleviku suhtes: kas doktorikraadijärgne õpe või võimalik akadeemiline töökoht PõhjaAmeerikas

Teadlikum

akadeemilise töökoha saamise keerukusest; püüdis sellele mitte liiga palju keskenduda; mõtles jätkata PõhjaAmeerikas 